УДК [631.15:65.011.44]:636.2.034

(C) 2015

Величко С. I., аспірант

(науковий керівник - доктор економічних наук, професор О. М. Супрун)

Харківський національний аграрний університет ім. В. В. Докучаєва

\title{
ЕКОНОМІЧНА ЕФЕКТИВНІСТЬ ВИРОБНИЦТВА МОЛОКА В СІЛЬСЬКОГОСПОДАРСЬКИХ ПІДПРИЕМСТВАХ
}

\section{Рецензент - доктор економічних наук, професор О. М. Супрун}

Розглянуто економічну ефективність виробництва молока в сільськогосподарських підприємствах. Досліджено економічну ефективність виробництва молока на прикладі СТОВ «АФ ім. Т. Г. Шевченка» Вовчанського району Харківської області. Для изього були використані основні статистичні показники результативності діяльності досліджуваного господарства. У результаті вивчення та узагальнення даних дослідження обтрунтовано, щзо СТОВ «АФ ім. Т. Г. Шевченка» є ефективним сільськогосподарським підприємством. Визначені основні шляхи підвищення рентабельності молочного тваринництва підприємства.

Ключові слова: молоко, молочне скотарство, виробництво, економічна ефективність, сільськогосподарське підприємство.

Постановка проблеми. Молочне скотарство нині знаходиться на стадії кризи, яка супроводжується різким скороченням поголів'я, зменшенням обсягів виробництва продукції та зниженням іiі економічної ефективності. Значною мірою це зумовлено ресурсною незбалансованістю виробництва, погіршенням його технологічних параметрів, порушенням паритетних взаємовідносин між виробниками і переробниками молочної продукції. Вивчення питання підвищення ефективності виробництва молока з метою забезпечення населення України продуктами харчування у відповідності до норм MO3 $є$ актуальним.

Важливим при цьому є комплексне дослідження виникаючих проблем, пов'язаних 3 організацією та технологічним процесом виробництва, переорієнтацією його на кінцеві результати, що також зумовлює актуальність названого дослідження.

Аналіз останніх досліджень і публікацій, у яких започатковано розв'язання проблеми, свідчить про те, що питанням розвитку молочного скотарства та проблемам, пов'язаним 3 економічною ефективністю виробництва молока, приділяється увага багатьох науковців. Цій темі присвячена значна кількість наукових праць і дослід- жень вітчизняних вчених, зокрема: В. Андрійчук [1], П. Березівський [2], М. Ільчук [3], П. Саблук [4], В. Месель-Веселяк [5], М. Пархомець [6], О. Супрун [7] та ін. Однак у зв'язку з актуальністю подальші наукові дослідження у цій галузі $€$ важливими та необхідними.

Мета дослідження: дослідити економічну ефективність виробництва молока в сільськогосподарських підприємствах.

Завдання дослідження: дослідити ефективність виробництва молока в сільськогосподарських підприємствах на прикладі СТОВ «АФ ім. Т. Г. Шевченка» Вовчанського району Харківської області та визначити шляхи підвищення рентабельності молочного тваринництва.

Матеріали та методи дослідження. Теоретичною та методичною основою дослідження були основні положення економічної теорії, теорії управління, наукові праці вітчизняних і зарубіжних учених із проблем економічної ефективності виробництва молока сільськогосподарськими підприємствами. Для дослідження даної проблеми були використані основні статистичні показники результативності діяльності СТОВ «АФ ім. Т. Г. Шевченка» Вовчанського району Харківської області. Для досягнення поставленої мети використані методи системного аналізу, економікостатистичний та абстрактно-логічний (теоретичні узагальнення та формулювання висновків).

Результати досліджень. Важливим елементом молочного виробництва СТОВ «АФ ім. Т. Г. Шевченка» $€$ молочнотоварна ферма, на якій утримується симентальська порода корів, ці корови добре пристосовані до українських умов і тому можуть бути основою стада. Зараз на фермі загалом 130 дійних корів. У цьому господарстві застосовують доїльні установки та агрегати індивідуального доїння в доїльне відро. Влітку корів випасають на пасовищі.

Досліджуючи ефективність виробництва молока, необхідно враховувати те, що вона залежить від трьох складових: кількості виробленого і реалізованого молока, понесених витрат на його виробництво та ціни реалізації. 


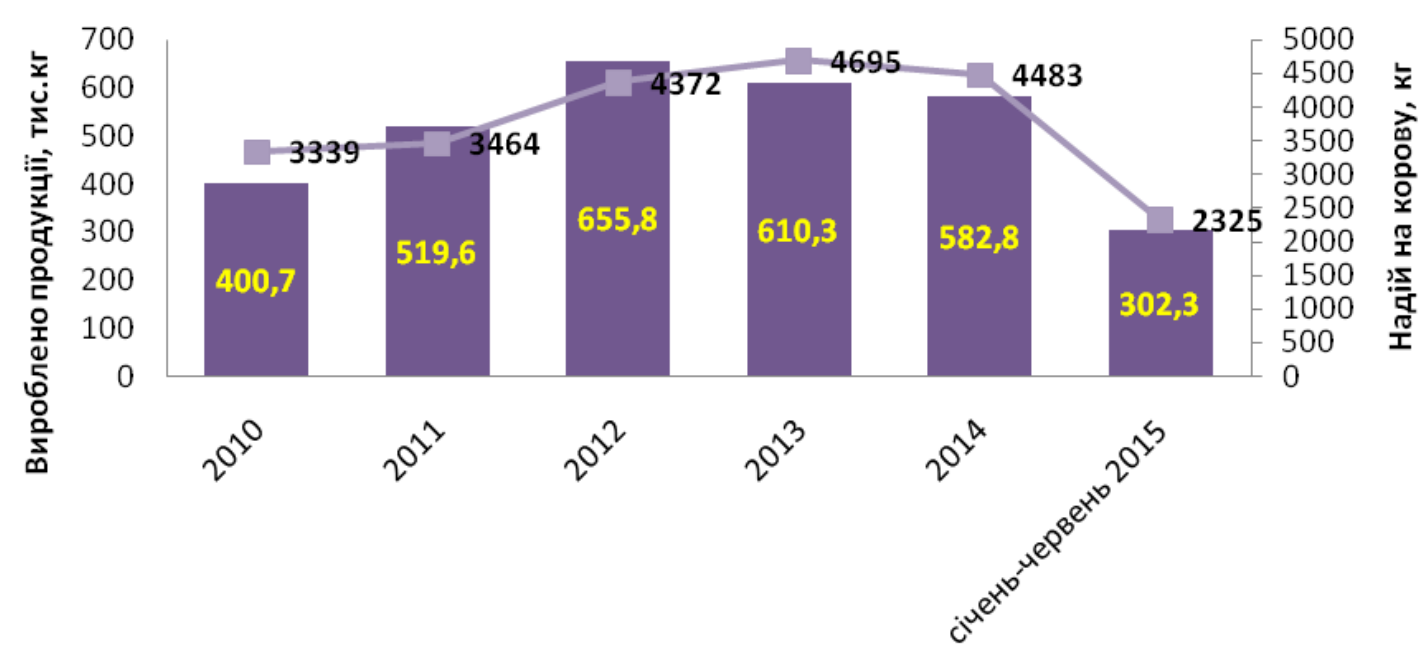

Роки

Вироблено продукції, тис. кг - - Надійна корову, кг

Рис. 1. Динаміка виробництва молока в СТОВ «Агрофірма ім. Т. Г. Невченка»

Джерело: сформовано автором за статистичними даними СТОВ «АФ ім. Т. Г. Шевченка» (форма 24 с.-г.) [10].

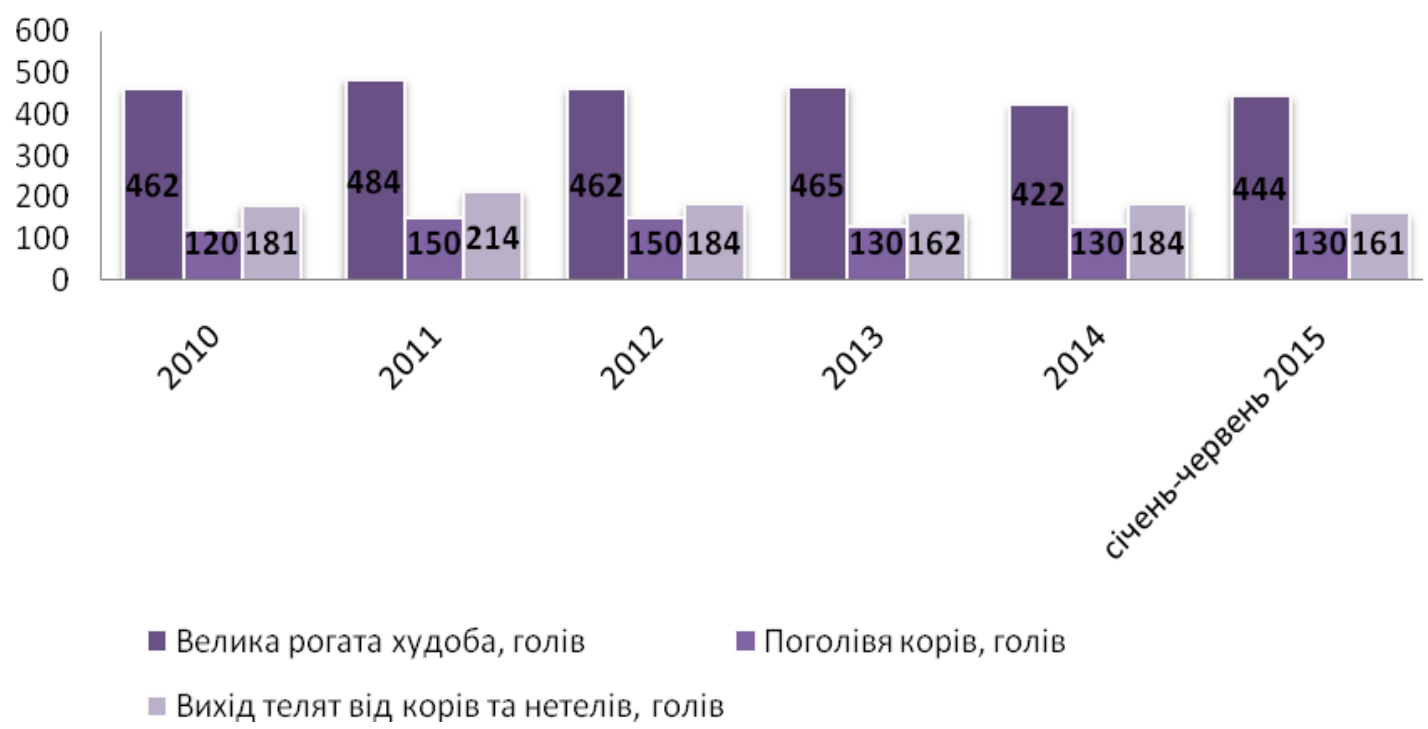

Рис. 2. Динаміка поголів'я в СТОВ «Агрофірма ім. Т. Г. Шевченка»

Джерело: сформовано автором за статистичними даними СТОВ «АФ ім. Т. Г. Шевченка» (форма 24 с.-г.) [10].

У молочному скотарстві господарства поголів'я корів упродовж останніх років незмінне та спостерігається незначне зменшення виробництва молока (рис. 1, 2). Виробництво молока в 2014 році порівняно з 2013 роком знизилося на 27,5 тис. кг та становило 582,8 тис. кг. Разом 3 цим продуктивність дійного стада також зменшилась на 212 кг і становила в 2014 році 4483 кг молока на корову.

За січень-червень 2015 року отримано 302,3 тис. кг молока, а продуктивність за ці шість місяців становить 2325 кг молока на корову. Основною причиною зменшення виробництва молока стало зниження продуктивності молочного стада.

Молочне скотарство є важливим елементом виробництва даного сільськогосподарського підприємства.

Поголів'я великої рогатої худоби господарства в 2014 році становило 422 голови, що на 43 голови менше порівняно з 2013 роком. Найбільша його чисельність спостерігалася в 2011 році484 голови. Щодо поголів'я дійного стада, то впродовж останніх років воно незмінне. Разом 3 
цим в 2012 році в господарстві налічувалось 150 корів, а вже з 2013 року 130 голів. У господарстві застосовують цілорічні отелення корів, але найбільшу кількість телят одержують у зимовий період року.

У молочному бізнесі основними факторами прибуткового виробництва $є$ низька собівартість і висока ціна продукції. Витрати на виробництво молока залежать від обсягів і ефективності використання активів. Зазвичай їх поділяють на поточні і накладні. Поточні - це витрати на корми, підстилку, ветеринарні послуги, збут продукції, пально-мастильні матеріали, електроенергію, ремонт та інші [8].

Аналізуючи рисунок 3, можна зробити висновок, що найбільш вагомими у СТОВ «АФ ім. Т. Г. Шевченка» $є$ витрати на корми. Структура матеріальних витрат на виробництво молока показує, що в господарстві найбільшу частку займає вартість оплати праці з відрахуваннями та кормів (у 2014 році - 38,8 \% і 29,9\%).

Істотних змін структура виробничих витрат упродовж останніх років не зазнавала за винятком незначного зниження частки оплати праці 3 відрахуваннями і зростання вартості кормів.

Досліджуючи економічну ефективність виробництва молока, слід враховувати, що обов'язко- вим елементом технологічного виробничого процесу $є$ організація постійного відтворення маточного поголів'я за рахунок вирощування повноцінного і більш продуктивного ремонтного молодняку.

Проте, як свідчить практика, за існуючих підходів до розрахунку витрат на виробництво молока та рівня реалізаційних цін на яловичину вирощування ремонтного молодняку для відтворення власного поголів'я у господарствах $є$ збитковим.

Тому якщо говорити про стабілізацію, а в подальшому й нарощування виробництва молока, то його економіку ми повинні розглядати нерозривно $з$ економікою відтворення маточного поголів'я, тобто витрати на вирощування майбутньої корови повинні відшкодовуватися одержаним прибутком від реалізації молока за період іiі продуктивного використання.

Лише за такої умови можна досягти достатньої ефективності галузі молочного скотарства в цілому [8].

Слід також відмітити, що в сучасних умовах розвитку штучне запліднення стало основним технологічним засобом відтворення тварин (рис. 4).

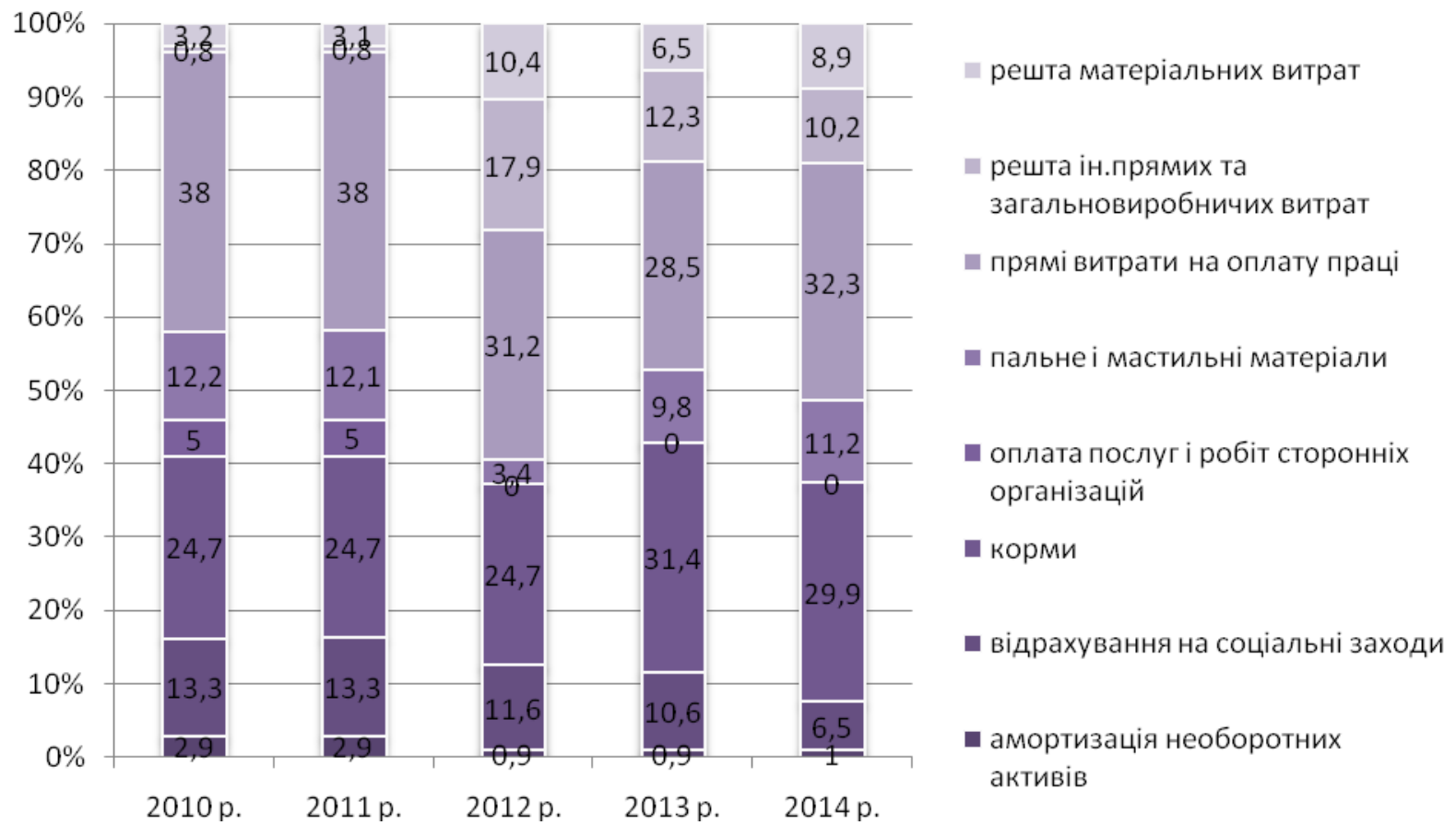

Рис. 3. Структура витрат на виробництво молока в СТОВ «Агрофірма ім. Т. Г. Шевченка» Джерело: сформовано автором за статистичними даними СТОВ «АФ ім. Т. Г. Шевченка» (форма 50 с.-г.) [11]. 


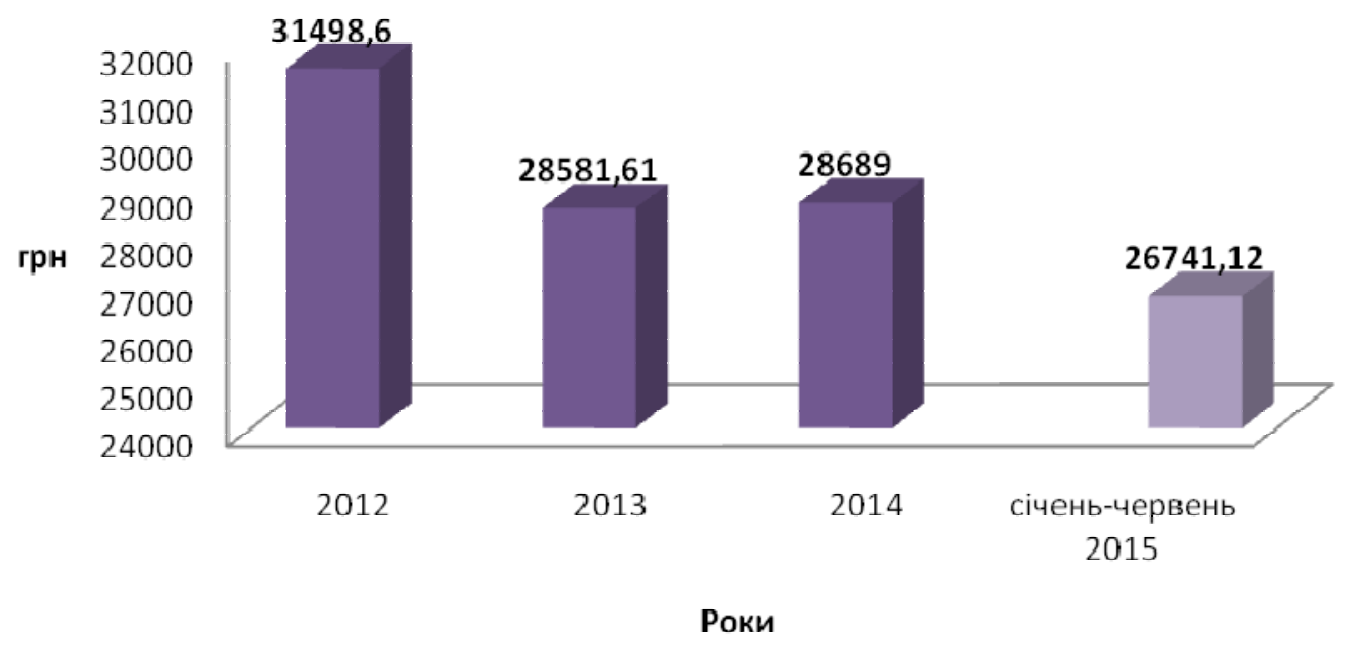

- Державне підприємство "Харківське обласне сільськогосподарське підприємство по племінній справі у тваринництві"

च ТОВ «Генетичні ресурси»

Рис. 4. Динаміка витрат на итучне запліднення корів, грн

Джерело: сформовано автором за статистичними даними СТОВ «АФ ім. Т. Г. Шевченка».

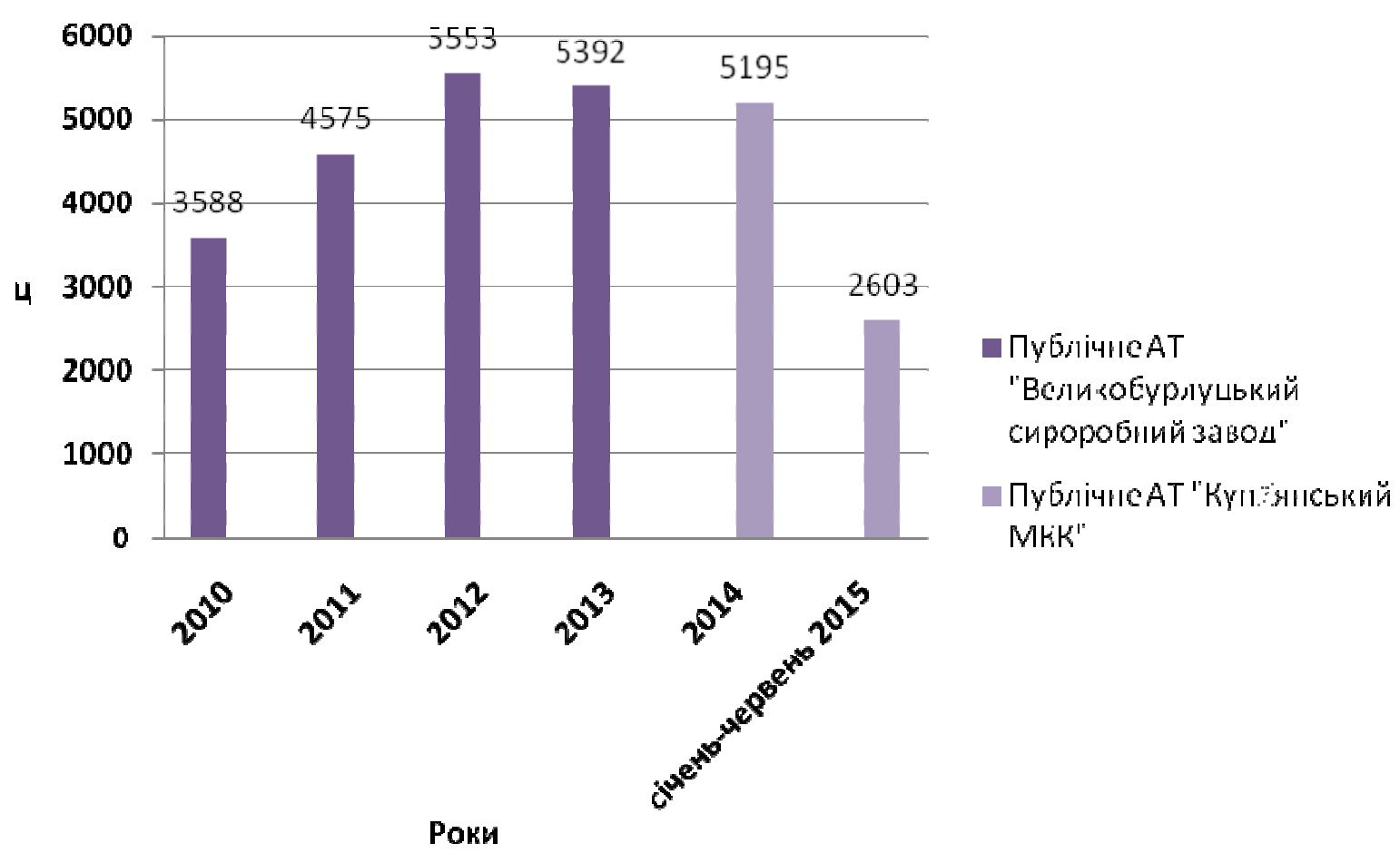

Рис. 5. Кількість реалізованого молока на молокопереробні заводи, и

Джерело: сформовано автором за статистичними даними СТОВ «АФ ім. Т. Г. Шевченка» (форма 21-заг.) [12].

Так, господарство до 2014 року користувалося послугами штучного запліднення державного підприємства «Харківське обласне сільськогосподарське підприємство по племінній справі у тваринництві» а з 2015 року - послугами ТОВ «Генетичні ресурси». 


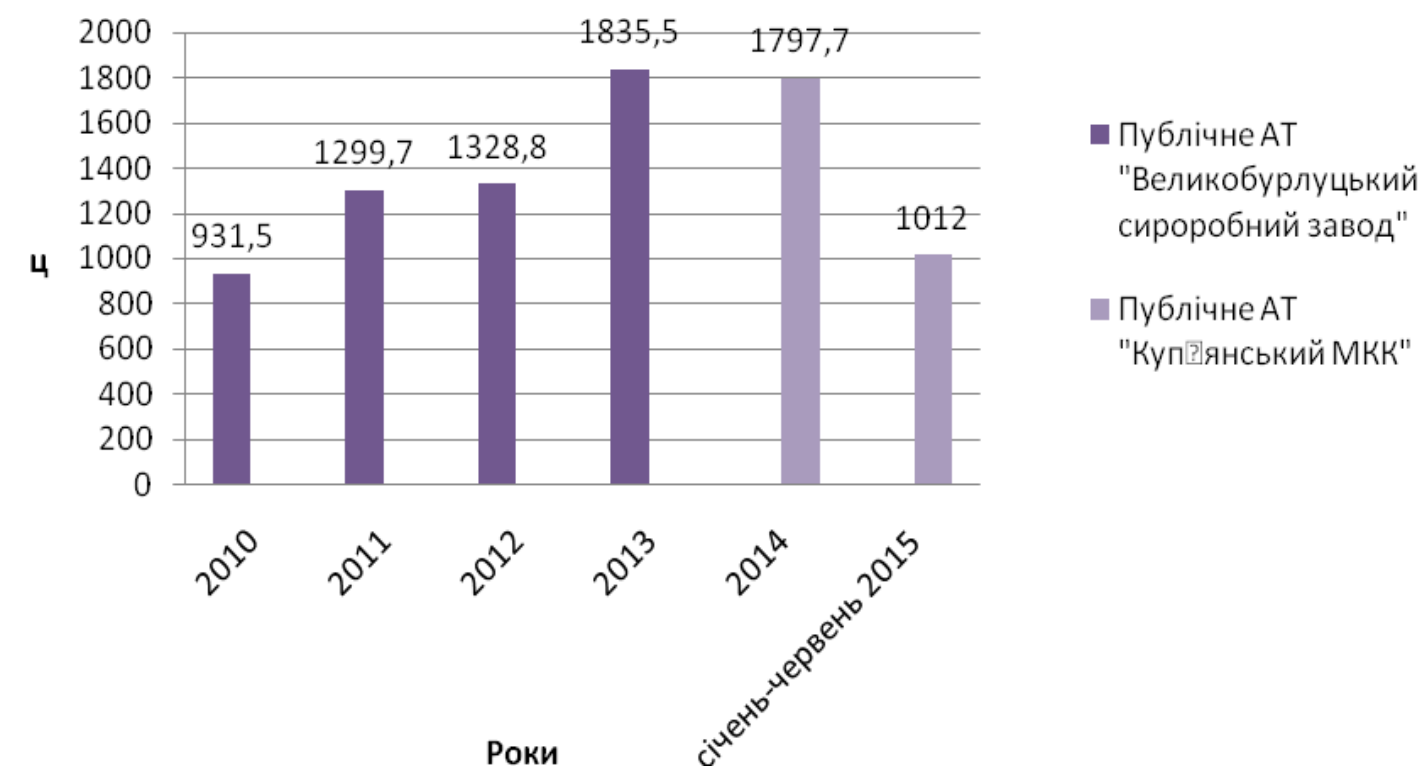

Рис. 6. Виручка від продажу молока до молокопереробних заводів, тис. грн

Джерело: сформовано автором за статистичними даними СТОВ «АФ ім. Т. Г. Шевченка» (форма 21-заг.) [12].

Ціна спермопродукції бугаїв-плідників в 2015 році становить 42,20 грн/1 спермодозу (сума 3 ПДВ), а в 2014 році - 36 грн/1 спермодозу (сума 3 ПДВ). Штучне запліднення є більш прогресивним та економічно вигідним способом відтворення стада, що позитивно відображається на економічній ефективності господарства. Важливою умовою розвитку молочного виробництва $\epsilon$ відтворення стада. Так, вихід телят за січень-червень 2015 року становить 125 телят на 130 корів, або $96 \%$. Окрім того, введено нетелів в основне стадо - $28 \%$, або 36 голів. Збереження телят у досліджуваному підприємстві сягає $100 \%$.

Господарство протягом досліджуваного періоду часу реалізовувало молоко до 2014 року до ПАТ «Великобурлуцький сироробний завод», а вже з 2014 року молоко почали здавати до ПАТ «Куп'янський МКК» (рис. 5).

Так, за 2014 рік було здано на молокопереробний завод 5195 ц молока, що на 197 ц менше, ніж у 2013 році, а за січень-травень цього року здано вже 2603 ц молока. 32013 року спостерігається зменшення здачі молока до молокопереробного заводу. Найбільші обсяги здачі молока до молокопереробного заводу були в 2012 році 5553 ц, водночас на підприємстві дійне стадо становило 150 голів. Але ПАТ «Великобурлуцький сироробний завод» збанкрутував, не погасивши заборгованість за здане молоко перед СТОВ «АФ ім. Т. Г. Шевченка» в сумі 210 тис. грн. На сьогодні вже інший молокопереробний завод ПАТ «Куп'янський МКК» заборгував підприємству 586 тис. грн за прийняте молоко.

У липні цього року середня закупівельна ціна на молоко першого гатунку для підприємства становила 4,70 грн/кг (сума 3 ПДВ). Водночас прибуток за шість місяців 2015 року від продажу молока становить 1012 тис. грн (рис. 6).

Перспективи галузі молочного скотарства в першу чергу залежатимуть від того, наскільки реально сьогодні вибудовуються партнерські відносини між усіма учасниками ринку, що дасть змогу через механізм еквівалентного ціноутворення створити необхідні економічні умови для збільшення поголів'я молочних корів за рахунок власного відтворення стада, а також зростання обсягів виробництва молока завдяки збільшенню продуктивності дійного стада.

Висновок. Молочне скотарство $є$ однією зі складових функціонування та розвитку аграрного виробництва України. Для виробників цей сектор у перспективі залишається вигідним, оскільки, незважаючи на досить високі першочергові інвестиції, сільськогосподарський товаровиробник може отримувати обігові кошти для вирішення невідкладних завдань. Досягнення високих рівнів прибутковості можливе лише за умови зниження собівартості та відлагодження дисципліни розрахунків переробників молока 3 його виробником. 
СТОВ «АФ ім. Т. Г. Шевченка» $є$ ефективним сільськогосподарським підприємством. Для підвищення рентабельності виробництва молока першочергове значення має зростання рівня продуктивності корів, раціональне використання виробничих ресурсів, а також широке впровад-

\section{БІБЛІОГРАФІЯ}

1. Андрійчук В. Г. Теоретико-методологічне обгрунтування ефективності виробництва / В. Г. Андрійчук // Економіка АПК. - 2005. - №5. - С. 5263.

2. Березівський П. Економічна ефективність скотарства та шляхи іiі підвищення / Березівський П. - Львів : Укр. технології, 1998. - 156 с.

3. Ільчук М. М. Ефективне функціонування молокопродуктового підкомплексу України / М. М. Ільчук. - К. : Нічлава, 2004. - 312 с.

4. Саблук П. Т. Економіка виробництва молока і молочної продукції в Україні : монографія / [за ред. П. Т. Саблука і В. І. Бойка]. - К. : ННЦ IAE, 2005. - $340 \mathrm{c}$.

5. Месель-Веселяк В.Я. Оптимальні розміри сільськогосподарських формувань промислового типу в Україні / В. Я. Месель-Веселяк // Економіка АПК. - 2008. - №3. - С. 13-20.

6. Пархомець М. К. Організаційно-економічні основи розвитку молокопродуктового підкомплексу в ринкових умовах : монографія / М. К. Пархомець. - Тернопіль : Економічна думка, 2005. - ження інноваційних технологій виробництва i покращання якості продукції. Це питання набуває все більшого значення, оскільки поліпшення якості молочної продукції рівнозначне збільшенню обсягу надходження додаткової виручки.

$345 \mathrm{c}$.

7. Супрун О. М. Економічне регулювання аграрного виробництва : монографія / О. М. Супрун. К. : ННЦ «Ін-т аграр. економіки», 2011. - 350 с.

8. Костенко В. Економіка виробництва молока / В. Костенко // Агробізнес сьогодні. - 2015. №8 (303). - C. 54-56.

9. Самаріна I. Сімейні ферми та молочні кооперативи: прибуток і заможність селян / I. Самаріна // Агробізнес сьогодні. - 2014. - №18 (289). C. $48-50$.

10. Форма 24-сг (місячна) : Стан тваринництва січень-червень 2015 року СТОВ «АФ ім. Т. Г. Шевченка».

11. Форма 50-сг (річна) : Основні економічні показники роботи сільськогосподарських підприємств за 2014 рік СТОВ «АФ ім. Т. Г. Шевченка».

12. Форма № 21-заг (місячна) : Реалізація сільськогосподарської продукції за січень-червень 2015 року СТОВ «АФ ім. Т. Г. Шевченка». 